\title{
The Use of Video Media in an Effort to Improve the Learning Outcomes of Civics in Class II Students of SDN 4 Jalatunda
}

\section{Rusmiati}

SD Negeri 4 Jalatunda

roseevelyn028@gmail.com

\begin{abstract}
Article History
accepted 14/11/2020

approved $21 / 11 / 2020$

published 26/11/2020

Abstract

Based on the results of observations, it shows that Civics learning is still carried out conventionally where teachers still use learning media that is limited to textbooks. This causes students to act less in the learning process and the learning outcomes obtained are low. Focusing on the problem, this study aims to improve planning, implementation and assessment of Civics learning using video media. This classroom action research uses qualitative and quantitative approaches. In practice, the study, which consisted of three cycles, was carried out collaboratively with fellow teachers. The research was conducted in the odd semester of the 2020/2021 school year at SDN 4 Jalatunda with the research subjects being all grade II students. The research data were collected through observation, interviews, field notes, documentation and tests. The results of data analysis indicate that the use of video media can improve student learning outcomes in class II Civics learning at SDN 4 Jalatunda. This can be seen from (1) students' cognitive learning outcomes have increased from an average value of 71.43 in the first cycle to 85.71 in the second cycle and 92.86 in the third cycle (2) the affective domain has increased from an average value of 64,29 in cycle I to 82.14 in cycle II and 92.86 in cycle III, and (3) in psychomotor increased from an average value of 72.32 in cycle I to 80.81 in cycle II and 89.29 in cycle cycle III. Seeing the results of this study, classroom action research in the use of video media in Civics learning needs to be applied and developed in order to improve the quality of education in the future.
\end{abstract}

Keywords: learning outcomes, video media, civics

\begin{abstract}
Abstrak
Berdasarkan hasil observasi, menunjukkan pembelajaran PKn masih dilaksanakan secara konvensional dimana guru masih menggunakan media pembelajaran yang terbatas pada buku ajar. Hal ini menyebabkan siswa kurang bertindak dalam proses pembelajaran dan hasil belajar yang diperoleh rendah. Berfokus pada masalah, penelitian ini bertujuan untuk memperbaiki perencanaan, pelaksanaan dan penilaian pembelajaran PKn dengan menggunakan media video. Penelitian tindakan kelas ini menggunakan pendekatan kualitatif dan kuantitatif. Dalam prakteknya, penelitian yang terdiri dari tiga siklus ini dilaksanakan secara kolaboratif dengan rekan guru. Penelitian dilaksanakan pada semester ganjil tahun pelajaran 2020/2021 di SDN 4 Jalatunda dengan subjek penelitian adalah seluruh siswa kelas II. Data penelitian dikumpulkan melalui observasi, wawancara, catatan lapangan, dokumentasi dan tes. Hasil analisis data menunjukkan bahwa penggunaan media video dapat meningkatkan hasil belajar siswa pada pembelajaran PKn kelas II SDN 4 Jalatunda. Hal ini terlihat dari (1) Hasil belajar kognitif siswa mengalami peningkatan dari nilai rata-rata 71,43 pada siklus I menjadi 85,71 pada siklus II dan 92,86 pada siklus III (2) ranah afektif meningkat dari nilai rata-rata 64,29 pada siklus I menjadi 82,14 pada siklus II dan 92,86 pada siklus III, dan (3) pada psikomotor meningkat dari nilai ratarata 72,32 pada siklus I menjadi 80,81 pada siklus II dan 89,29 pada siklus III. Melihat hasil penelitian ini maka penelitian tindakan kelas dalam penggunaan media video dalam pembelajaran PKn perlu diterapkan dan dikembangkan dalam rangka meningkatkan mutu pendidikan di masa yang akan datang.

Kata kunci: hasil belajar, media video, pkn
\end{abstract}

Social, Humanities, and Education Studies (SHEs): Conference Series https://jurnal.uns.ac.id/shes

p-ISSN 2620-9284 e-ISSN 2620-9292 


\section{PENDAHULUAN}

Pendidikan di sekolah dasar merupakan tahapan awal dari program pembentukan karakter peserta didik. Khususnya dalam mata pelajaran PKn. PKn sebagai pelajaran yang membentuk karakter peserta didik, menciptakan peserta didik yang berbudi luhur, dan membangun budi pekerti peserta didik harus diajarkan secara tepat demi membentuk masa depan bangsa yang berkepribadian lebih maju. Pendidikan Kewarganegaraan secara kurikuler dirancang sebagai subjek pembelajaran yang bertujuan untuk mengembangkan potensi individu agar menjadi warga negara Indonesia yang berakhlak mulia, cerdas, parsitipatif, dan bertanggung jawab (Sunarso dkk, 2006: 1).

Senada dengan pernyataan di atas, Wahab (1997:3) mengemukakan bahwa "PKn di SD merupakan program pendidikan yang berlandaskan nilai-nilai Pancasila sebagai wahana untuk mengembangkan dan melestrikan nilai-nilai luhur dan moral yang berakar pada budaya Bangsa Indonesia yang diharapkan dapat menjadi jati diri yang diwujudkan dalam bentuk perilaku dalam kehidupan sehari-hari dari seluruh warga Negara Indonesia".

Berdasarkan pendapat para ahli di atas dapat disimpulkan bahwa PKn di SD merupakan program pendidikan yang bertolak dari dan memusatkan perhatian pada konsep, nilai, moral, norma, dan perilaku sesuai Pancasila dan UUD 1945 serta hak dan kewajiban sebagai warga negara.

Namun pembelajaran pendidikan kewarganegaraan berjalan tidak lepas dari banyaknya permasalahan yang ditemui di sekolah, khususnya di sekolah dasar. Rendahnya motivasi dan aktivitas belajar peserta didik, lemahnya pemahaman peserta didik dalam proses belajar mengajar, dan rendahnya hasil belajar peserta didik merupakan segelintir permasalahan yang ditemukan dalam pembelajaran PKn.

Salah satu faktor dalam meningkatkan hasil belajar peserta didik adalah dengan menggunakan alat dan metode belajar yang tepat (Slameto, 2003: 65 - 68). Metode mengajar adalah suatu cara yang harus dilalui didalam proses belajar mengajar. Metode belajar merupakan cara yang digunakan oleh guru dalam menyampaikan materi pembelajaran di kelas. Selain itu, Nana Sudjana (2005: 76) menambahkan metode pembelajaran adalah cara yang dipergunakan guru dalam mengadakan hubungan dengan peserta didik pada saat berlangsungnya pengajaran. Metode pembelajaran menyangkut dengan bagaimana cara yang digunakan oleh guru dalam proses belajar mengajar. Apabila guru menggunakan metode yang kurang baik, maka akan mempengaruhi belajar peserta didik yang tidak baik pula. Dan sebaliknya, apabila guru menggunakan metode pembelajaran yang baik maka akan memberikan pengaruh yang baik dalam proses belajar mengajar.

Dalam menggunakan metode pembelajaran yang digunakan, peran alat atau media pembelajaran juga memberikan pengaruh yang besar terhadap minat belajar peserta didik. Alat atau media pelajaran yang tepat akan membantu memperlancar penerimaan bahan ajar kepada peserta didik.

Secara umum di kelas II SD Negeri 4 Jalatunda, dalam mengajar guru hanya mengunakan media gambar yang ada di buku peserta didik. Bagi peserta didik media gambar kurang menarik perhatian mereka, karena peserta didik sudah terbiasa disajikan gambar-gambar dalam buku tema. Penggunaan media gambar yang terus menerus juga menyebabkan rendahnya motivasi dan keaktifan peserta didik dalam mengikuti pembelajaran. Hal ini berdampak pada rendahnya hasil belajar peserta didik kelas II di SD Negeri 4 Jalatunda khususnya Mupel PKn materi Persatuan dalam Keberagaman di Rumah. Oleh karena itu, guru harus berani mencoba menggunakan metode dan alat pelajaran yang dapat meningkatkan hasil belajar peserta didik. Salah satu media yang dapat digunakan oleh guru dalam proses belajar mengajar adalah media video. 
Berdasarkan latar belakang masalah di atas, maka akan dilakukan perbaikan dalam proses pembelajaran yaitu menggunakan media video agar dapat menarik motivasi dan keaktifan peserta didik yang berdampak pada peningkatan pemahaman dan hasil belajar peserta didik.

\section{METODE}

Pendekatan yang digunakan dalam penelitian ini adalah pendekatan kualitatif. Pendekatan kualitatif ini berkenaan dengan perbaikan atau peningkatan proses pembelajaran pada suatu kelas. Pendekatan kualitatif digunakan karena prosedur penelitian yang menghasilkan data deskriptif berupa kata-kata tertulis atau lisan serta perilaku yang diamati dari orang-orang atau sumber informasi. Sedangkan untuk melihat keberhasilan proses pembelajaran dengan pendekatan kualitatif didukung oleh data kuantitatif. Jenis penelitian yang dilaksanakan adalah Penelitian Tindakan Kelas (Classroom Action Research).

Menurut Arikunto, dkk (2007:58) "Penelitian Tindakan Kelas (PTK) adalah penelitian tindakan (action research) yang dilakukan dengan tujuan memperbaiki mutu pratik pembelajaran di kelasnya". Pendapat ini senada dengan Wardhani, dkk (2007:1.4) "Penelitian tindakan kelas adalah penelitian yang dilakukan oleh guru di dalam kelasnya sendiri melalui refleksi diri, dengan tujuan untuk memperbaiki kinerjanya sebagai guru, sehingga hasil belajar siswa menjadi meningkat".

Mengingat dalam suatu penelitian tindakan kelas peneliti perlu dibantu oleh pendamping sebagai rekan diskusi bagi peneliti, maka dalam hal ini peneliti meminta bantuan guru kelas sebagai pengamat dalam penelitian, mulai dari perencanaan tindakan, pelaksanaan tindakan, observasi, refleksi, dan revisi selama peneliti melakukan penelitian di SDN 4 jalatunda. Penelitian tindakan kelas ini dilaksanakan melalui tahap-tahap yang umumnya dilaksanakan dalam suatu penelitian tindakan kelas. Tahap-tahap tersebut biasa disebut dengan siklus, dimana setiap siklusnya meliputi perencanaan, pelaksanaan tindakan, observasi, evaluasi, dan refleksi. Tahap-tahap penelitian tindakan kelas yang bersifat spiral tersebut digambarkan oleh Hopkins sebagai berikut :

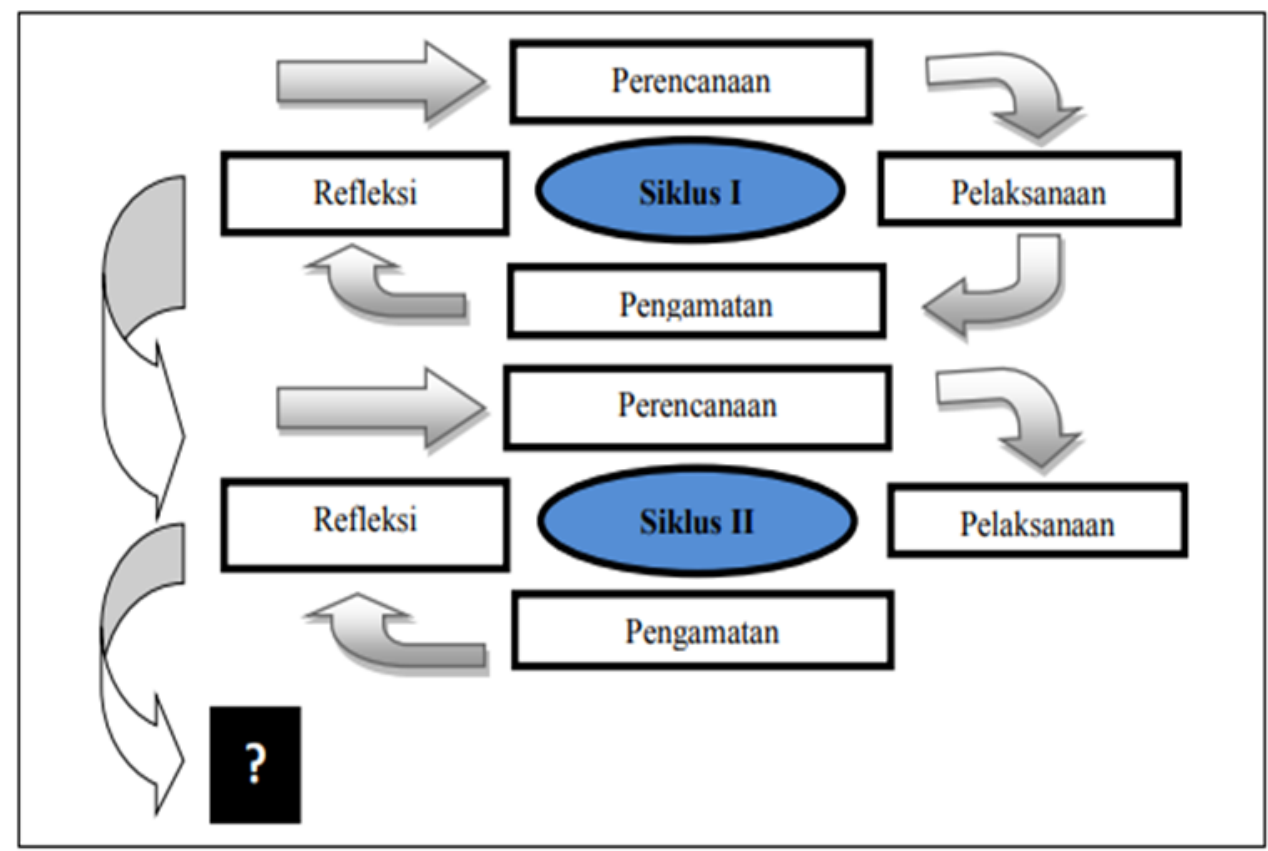

Gambar 1.1 Spiral Penelitian Tindakan Kelas Hopkins (Wiriaatmadja 2008: 66) 
Kegiatan penelitian dilaksanakan berdasarkan perencanaan tindakan yang telah ditetapkan, yaitu melaksanakan pembelajaran sesuai rencana pembelajaran yang telah dibuat. Fokus tindakan adalah penggunaan media video untuk meningkatkan pembelajaran PKn. Pada tahap pelaksanaan tindakan ini, proses pembelajaran dilaksanakan dengan menjalankan skenario pembelajaran yang telah dirancang dan terdapat dalam RPP.

Subjek penelitian yaitu peserta didik kelas II SD Negeri 4 Jalatunda yang berjumlah 14 peserta didik yang terdiri dari 4 peserta didik laki-laki dan 10 peserta didik perempuan. Penelitian dilaksanakan di SD Negeri 4 Jalatunda mulai bulan Oktober sampai dengan bulan November 2020.selama tiga siklus secara luring dengan satu pertemuan disetiap siklusnya. Siklus I dilaksanakan pada tanggal 2 november 2020. Siklus II dilaksanakan pada tanggal 9 November 2020. Siklus III dilaksanakan pada tanggal 20 November 2020. Teknik pengumpulan data yang dilakukan dengan observasi dan tes, baik pre test maupun post test. Observasi meliputi observasi keterlaksanaan model discovery learning melalui media video, sikap peserta didik dan keterampilan. Untuk hasil belajar menggunakan lembar LKPD dan lembar evaluasi.

\section{HASIL DAN PEMBAHASAN}

Penelitian ini dilakukan selama 3 siklus perbaikan pembelajaran. Pada siklus I pembelajaran dilaksanakan sesuai dengan rencana yang dibuat dan memperoleh hasil yang cukup baik yaitu siswa yang tuntas meningkat manjadi 10 siswa atau $71,43 \%$ dan siswa yang belum tuntas sebanyak 4 siswa atau $28,57 \%$ dengan nilai rata-rata kelas sebesar 73,57. Pelaksanaan perbaikan pada siklus II, dengan memperbaiki semua perangkat berdasarkan hasil refleksi yang ada. Setelah dilaksanakan perbaikan pada siklus II diperoleh hasil belajar siswa meningkat lagi menjadi 12 siswa atau 85,71\% dan siswa yang belum tuntas sebanyak 2 siswa atau $85,71 \%$ dengan rata-rata kelas sebesar 92,86\%. Berdasarkan data yang ada terjadi peningkatan sebanyak 2 siswa dari siklus I atau $14,29 \%$. Hal tersebut karena adanya perbaikan pada perangkat dan lebih memaksimalkan video yang digunakan. Setelah dilaksanakan perbaikan pada siklus III terjadi peningkatan lagi siswa yang tuntas menjadi 13 siswa atau 92,86\% dan siswa yang belum tuntas 1 siswa atau 7,14\%. Untuk siswa yang belum tuntas dikarenakan kemampuan siswa. Lebih jelasnya tentang peningkatan keberhasilan dalam setiap siklus disajikan pada tabel berikut ini.

Tabel 1. Hasil Belajar Slswa pada Siklus I, II, dan III

\begin{tabular}{ccccccc}
\hline No & Pembelajaran & $\begin{array}{c}\text { Siswa } \\
\text { Tuntas }\end{array}$ & Persentase & $\begin{array}{c}\text { Siswa } \\
\text { Tuntas }\end{array}$ & Persentase & $\begin{array}{c}\text { Rata-rata } \\
\text { Kelas }\end{array}$ \\
\hline 1. & Siklus I & 10 & $71,43 \%$ & 4 & $28,57 \%$ & 73,57 \\
2. & Siklus II & 12 & $85,71 \%$ & 2 & $14,29 \%$ & 78,93 \\
3. & Siklus III & 13 & $92,86 \%$ & 1 & $7,14 \%$ & 85,71
\end{tabular}

Berdasarkan tabel di atas dapat dijelaskan bahwa siswa yang tuntas terjadi peningkatan hasil belajar. Pada siklus I siswa tuntas sebanyak 10 siswa dan pada siklus II meningkat menjadi 12 siswa terjadi peningkatan 2 siswa atau 14,29\%. Pada siklus III siswa yang tuntas meningkat menjadi 13 siswa atau 92,86\%. Terjadi peningkatan lagi sebanyak 1 siswa atau $7,14 \%$. Agar lebih jelas tentang peningkatan hasil belajar dapat dilihat pada gambar diagram berikut ini. 


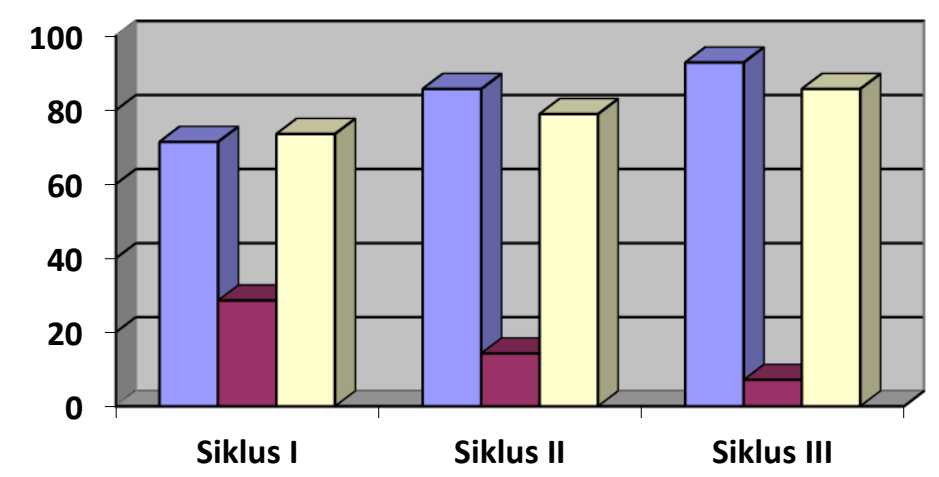

\section{口Siswa Tuntas 口Siswa Belum Tuntas QRata-rata Kelas \\ Gambar 1. HAsil Belajar Siswa pada Siklus I, II, dan III}

Berdasarkan hasil belajar yang diperoleh dapat disimpulkan bahwa perbaikan pembelajaran dengan menggunakan media video mampu meningkatkan hasil belajar siswa pada muatan pelajaran PKn. Perbaikan dinyatakan dihentikan dan dinyatakan berhasil.

\section{SIMPULAN}

Berdasarkan hasil penelitian yang dilakukan dalam tigas siklus perbaikan pembelajaran dapat disimpulkan bahwa: penggunaan media video mampu meningkatkan hasil belajar siswa dalam pembelajaran, terbukti pada siklus III siswa yang tuntas mencapai 13 siswa dari 14 siswa atau sebesar $92,86 \%$ dengan nilai ratarata kelas 85,71. Selain hasil belajar penggunaan media video juga mampu membangkitkan minat siswa dalam belajar sehingga berdampak terhadap pemahaman siswa.

\section{DAFTAR PUSTAKA}

Arikunto, Suhardjono dan Supardi. 2006. Penelitian Tindakan Kelas. Jakarta: Bumi Aksara.

Aqib, Zainal, dkk. 2011. Penelitian Tindakan Kelas untuk Guru SD, SLB, dan TK. Bandung: YramaWidya.https://hjnina.wordpress.com/2016/12/08/pembelajarantematik-terpadu/ (diakses tanggal 13 Oktober pukul 10.00)

Majid, Abdul. 2014. Pembelajaran Tematik Terpadu. Bandung: PT. Remaja Rosdakarya https://www.kajianpustaka.com/2019/03/penelitian-tindakan-kelasptk.html (diakses tanggal 13 Oktober 2020 pukul 13.20)

Sunarso, dkk. 2006. Pendidikan Kewarganegaraan untuk Perguruan Tinggi. Yogyakarta: UNYPress

Slameto. (2013). Belajar dan Faktor-Faktor yang Mempengaruhinya. Jakarta: PT Rineka Cipta

Mulyatiningsih, Endang. 2011. Metode Penelitian Terapan Bidang Pendidikan. Bandung: Alfabeta.

Padmono, Y. 2010. Kekurangan dan kelebihan, Manfaat Penerapan PTK. Online: edukasi.kompasiana.com.

Hopkins, David. 1993. A Teacher's Guide to Classroom Research. Philadelphia: Open University Press. https://www.dosenpendidikan.co.id/hasil-belajar/ (diakses 
SHEs: Conference Series 3 (3) (2020) 869-874

tanggal 13 Oktober pukul 13.30) http://digilib.uinsby.ac.id/10922/5/bab\%202.pdf (diakses tanggal 13 Oktober pukul 14.30)

Mufarokah, Anissatul. 2009. Strategi Belajar Mengajar. Yogyakarta: TERAS Sanjaya, Wina. 2008. Perencanaan dan Desain Sistem Pembelajaran. Jakarta: Kencana Sanjaya, Wina. 2006. Strategi Pembelajaran. Jakarta: Prenada Media 